\title{
The Influence of Pension Scheme Maturity on Investment Strategies of Pension Funds in Kenya
}

\author{
Wilson Ngugi ${ }^{1}$, Amos Njuguna ${ }^{1} \&$ Francis Wambalaba ${ }^{1}$ \\ ${ }^{1}$ Chandaria School of Business, University States International University (USIU)- Africa, Nairobi, Kenya \\ Correspondence: Wilson Ngugi, Chandaria School of Business, USIU-Africa, Nairobi, Kenya. E-mail: \\ wmbugua6@gmail.com
}

Received: July 21,2018

Accepted: August 30, 2018

Online Published: September 5, 2018

doi:10.5539/ijbm.v13n10p1

URL: https://doi.org/10.5539/ijbm.v13n10p1

\begin{abstract}
The longevity risk borne by members of defined contribution pension schemes and the funding risk borne by sponsors of defined benefit pension funds have shifted attention to the investment strategies employed by pension funds. We use secondary data from 206 occupational retirement benefits schemes in Kenya, to examine the influence of pension scheme maturity on investment strategies. We then triangulate the results using focused group discussions with industry experts. Results from the regression models indicate that scheme maturity does not influence the investment strategies of occupation schemes in Kenya contrary to life cycle theory. The Retirement Benefits Authority and trustees of retirement benefits schemes in Kenya are advised to offer members' investment choices coupled with education to enable them make decisions to reduce their exposure to risky assets as they age.
\end{abstract}

Keywords: investment strategy, pension scheme, risky assets, longevity risk, life expectancy, scheme maturity

\section{Introduction}

Increasing life expectancy and a fall in birth rates especially in developed countries are contributing to an increase in old age dependency ratio (World Economic Forum [WEF], 2017; Mercer, 2016). The average life expectancy at birth has increased from 67.7 to 78.2 year for 27 developed countries based on United Nations data over the last 40 years while average fertility rate for the same countries has reduced from 2.43 to 1.8 in the last 30 years. The net effect has been an increase in the average old age dependency ratio from 16.9 in 1980 to 21.2 in 2010 for these countries (Mercer, 2016). In China, the most populous country in the world, life expectancy increased remarkably from 40 to 69 years between 1969 and 1982 due to improvement in the health care system especially in rural areas (Guo, 2017). The country's life expectancy further improved to 76.4 years by 2016 (World Health Organization [WHO], 2018) while old age dependency ratio was 14.5 putting pressure on its pension system (Organization of Economic Development and Cooperation [OECD], 2017). The situation is expected to get worse since the global population aged over 65 years is projected to increase from the current 600 million to 2.1 billion by 2050 due to advances in medical technologies and changes in lifestyle. This will result in a population of a smaller workforce supporting growing number of retirees by 2050 . The fact that the retirement age has not been increased at the same rate as life expectancy compounds the problem (WEF, 2017). To address the challenges of increasing life expectancy, countries need to review their pension systems, retirement age and encourage older people to continue working especially for publicly-financed retirement benefits (Mercer, 2016).

The investment strategies of pension schemes document the Trustees' decisions on asset allocation, investment manager choice and investment style among others (Stanko, 2002). The investment strategy determines the mix of investments to achieve the scheme's risks and returns objectives. It is the reference point for the fund managers in their daily management of portfolios per the mandate delegated to them by boards of trustees (Asebedo \& Grable, 2004). Studies indicate that asset allocation is a key driver of financial performance of pension funds. According to Brinson, Hood and Beebower (1986) and Brinson, Singer and Beebower (1999) asset allocation decision between equity and fixed income investments plays a greater role than the tactical movements of holdings within asset classes in shaping fund performance. The investment strategies of pension funds are relevant not only from the perspective of retirement income but also because of their impact on the development of capital markets and the supply of capital for innovative enterprises. In addition, capital market 
development in turn affects the range of investment products and the extent of diversification of pension fund portfolios (OECD, 2000). Pension funds are also increasing their investment exposures in non-traditional assets such as private equity, property, infrastructure and hedge funds among other providing the much needed long term capital for investment in various critical sectors of the global economy (OECD, 2013).

The retirement benefits sector in Kenya comprises the following schemes; mandatory and contributory National Social Security Fund (NSSF), Non Contributory Pay-As-You-Go (PAYG) civil service pension schemes, private and voluntary contributory occupational pension schemes and individual contributory schemes (Raichura, 2008). The Retirement Benefit Authority Act of 1997 laws of Kenya set up the Retirement Benefit Authority (RBA) to regulate and supervise the retirement benefits schemes among other duties. According to RBA (2017) retirement benefits assets of 1,241 pension schemes in Kenya amounted to Ksh 913 (\$9.13) billion as at 31 December 2016. The pension schemes had increase to 1,271 by 31 December 2017 and total assets had crossed the Ksh 1 trillion ( $\$ 10$ billion) mark to Ksh 1.08 trillion (RBA, 2018). The National Social Security Fund (NSSF) is the largest retirement benefits scheme in Kenya (RBA, 2018). According to the NSSF report and financial statements for the year ended 30 June 2016, NSSF assets totalled Ksh172 (\$1.72) billion, held by 2.4 million active members and 73367 registered employers. NSSF members contributed Ksh13 (\$0.13) billion in 2016 (NSSF, 2017).

Prior studies on the influence of scheme maturity on investment strategies reported contradictory results. Bikker, Broeders and Hollanders, (2012) and Alestalo and Puttonen (2006) found a negative relationship between average age of pension scheme members and investment in risky assets in line with lifecycle theory. In contrast, Lucas and Zeldes (2009) and López-Villavicencio and Rigot (2013) found no relationship between the two variables in their studies. This study contributes to this debate by investigating the influence of average age of scheme members, as a proxy for pension scheme maturity, on occupational retirement benefits schemes in Kenya investment in risky assets.

A number of studies reviewed used various proxies for scheme maturity due to unavailability of data on age of members. Lucas and Zeldes, (2009) used the active members divided by total membership represented by active, inactive and retired members, López-Villavicencio and Rigot (2013) and Reid (2014) measured maturity by the ratio of retired members to active members with a higher ratio an indication of more mature scheme while Macha and Shulia (2013) used the ratio of active members to those receiving annuities. This study used the average age of all scheme members a better measure of scheme maturity. The studies reviewed on the influence of pension scheme maturity on investment strategies were carried out in mature pension markets of America (Lucas \& Zeldes, 2009; López-Villavicencio \& Rigot, 2013), and Europe (Alestalo \& Puttonen, 2006; Bikker et al., 2012). This study sought to improve on prior studies and contribute to the studies on emerging pension market in African, building on the work done by Macha and Shulia (2013) in Tanzania. The objective of the study was to determine the influence of the average age of scheme members on investment strategies of occupational retirement benefits schemes in Kenya.

The rest of this paper covers the following areas; section two starts with the theory that underpins the study followed by a review of empirical studies and hypotheses development. Section three covers the research design and model specification. The study results are detailed in section four while the last section lays out the study conclusions and implications.

\section{Literature Review}

\subsection{Theoretical Review}

Franco Modigliani and Richard Brumberg pioneered the life cycle theory in 1950s. Initially the life cycle theory was on choices people make on their consumption pattern over the years given their income levels. The theory explains why people save for retirement during working life and spread their consumption based on their need at different stages of life independent of their income over time (Deaton, 2005). In 1963 Modigliani and Ando extended the life cycle theory from households to aggregate economy. The theory was used to address the challenges of providing for aging populations in developed countries, study the roles of private and public sectors in providing for retirement income and the effects of demographic changes on retirement systems and the economies (Massachusetts Institute of Technology [MIT], 2005).

Life cycle investment theory deals with transferring consumption across time and contingencies throughout the entire life cycle of the individual. Retirement savings shifts consumption from high earning years to retirement years. In contrast, loans and mortgage allow individuals to consume more in the present by borrowing against future expected income (Hogan, 2007). Life-cycle investing for those nearing retirement requires savings to be invested in safe assets to the extent appropriate for personal circumstances (Hogan, 2007; Kintzel, 2007). Life-cycle investment strategies were designed in the United States and United Kingdom to ensure that defined 
contribution plan members who do not make their own investment decisions have a reasonably appropriate risk/return profile over the years especially as they near retirement (Tower Watson, 2010).

The study relied on life cycles theory to examine the influence of the average age of scheme members; a proxy for scheme maturity, on the scheme's investment strategy represented by the percentage of scheme's funds invested in risky assets. The theory postulates that there is an inverse relationship between investment in risky assets and the age of the investors. Accordingly, pension schemes with older members would be expected to invest less in risky assets compared to schemes with younger members.

\subsection{Influence of Scheme Maturity on Investment Strategies}

Various studies have investigated the relationship between the age of pension scheme members as a proxy for the maturity of the pension scheme and investment in risky assets with mixed results. Alestalo and Puttonen (2006) examined asset allocation by 44 Finnish pension schemes. The study used members' age as the independent variable and actual asset allocation for equity and fixed income as the dependent variables. Pearson correlation and regression analysis were used to test the study hypotheses. The results of the study indicated that the less mature pension schemes invested more in equity than the mature schemes. The latter investing more in fixed income instruments in line with life cycle theory. An increase of one year in the average age of pension scheme members resulted in an increase of $2.3 \%$ in the amount invested in fixed income securities and a decrease of $1.7 \%$ in equity investment. Lucas and Zeldes (2009) carried out a study of the influence of plan maturity on investment in equity for 109 States and 87 Local Authorities pension plans in the United States. The ratio of active members to total scheme membership was used as a proxy for the age or maturity of the pension scheme. Scheme maturity was the independent variable while the percentage of the total scheme asset allocated to equity was the dependent variable. Multiple regression analysis was used to test the study hypotheses. The results indicated no statistically significant relationship between scheme maturity and investment in equity.

Bikker et al. (2012) investigated the impact of pension scheme participants' age on pension scheme asset allocation of 378 Dutch pension funds. Strategic equity allocation was the study's dependent variable, average age of active and all scheme participants were the independent variables. Regression analysis was employed to study the relationships between the independent and dependent variables. The study reported that pension schemes with higher average age of scheme members had a lower equity allocation than pension schemes with lower average age. Bikker et al., (2012) recommended use of investment policies that focused on different age groups within a pension scheme as opposed to average age based investment policies, views similar to those of Tuelings and De Vries (2006). López-Villavicencio and Rigot (2013) investigated determinants of defined benefit pension schemes investing in private equity in United States of America and Canada using data from CEM Benchmarking for the period 1996 to 2011. They used the ratio of retired pension scheme members to the active members as a measure of plan maturity. Tobit model was used for data analysis. The results indicated a negative relationship between scheme maturity and allocation to equity while schemes did not consider the age of members in private equity investment.

Macha and Shulia (2013) deployed a mixed research design and carried a cross-sectional study of determinants of Tanzanian pension schemes investment in risky assets. The dependent variable was the percentage of pension scheme assets invested in equities a proxy for investment in risky assets while the ratio of active scheme members to those receiving annuities was the independent variable. Results of regression analysis indicated that schemes with higher ratio of active members to annuitants invested more in equities. Boon, Briere and Rigot (2017) investigated the influence of characteristics of pension schemes on allocation to risky assets of 600 plans in the United States, Canada and the Netherlands. The independent variable was the percentage of retired pension plan members, the higher the percentage the more mature the plan. The dependent variables were percentage of the total pension scheme assets invested in equities, risky fixed income and alternatives. Regression analysis results found a statistically significant relationship between pension scheme maturity and investment in risky assets. An increase of $10 \%$ in retired members resulted in a $0.1 \%$ reduction in amounts invested in equities.

\subsection{Study Hypotheses}

Most defined contribution pension plans follow default investment options as many members of these plans are incapable or unwilling to choose investment strategies among the great variety offered to them. There is consensus that life-cycle investment strategy is desirable default option due to decreasing risk exposure as the individual ages (Antolin, Payet, \& Yermo, 2010). In Kenya individual pension scheme members do not decide how their funds are investment and hence the board of trustees formulates default investment option applicable to all members which should take into account the age profiles of the members. 
Based on the theoretical and empirical reviews the study hypotheses were formulated as follows;

H1: Pension scheme maturity has no influence on investment strategies of occupational retirement benefits schemes in Kenya.

H2: Pension scheme maturity has an influence on investment strategies of occupational retirement benefits schemes in Kenya

\section{Methods}

This study employed explanatory research design to investigate the influence of scheme maturity on investment strategy. The study adopted a cross sectional and mixed research design and collected data from pension schemes as at December 31, 2016. Focus group discussions with investment experts were used to triangulate the results of quantitative data analysis. Pension scheme maturity was measured by the average age of scheme members as at December 31, 2016 while investment in risky assets (quoted, unquoted and private equity and offshore investment) expressed as a percentage of the scheme's fund value was used as a proxy for scheme investment strategy.

The study's population consisted of 442 segregated occupational retirement benefits schemes per the Retirement Benefits Authority industry report for 2015 (RBA, 2016). A sample size of 210 pension schemes was computed using Yamane's (1967) formula (sample tolerance error 0.05). A secondary data collection template was developed to collect data from the sampled scheme administrators since secondary data on occupational retirement benefits schemes in Kenya is not publicly available. The data included scheme fund value and average age of members. The amount invested by each scheme in risky assets comprising of quoted and unquoted equities, offshore investment and private equity. Total invested in risky assets as a percentage of fund value was used as a proxy for investment strategies. Templates with complete data for the study variables were received for 206 pension schemes.

Pearson correlation was used to determine the relationship between the independent and dependent variable while regression analysis was used to test the hypotheses on the influence of scheme maturity on investment strategy. Focus Group Discussions were conducted with investment experts to validate the results.

The model was specified as;

$$
\begin{aligned}
& \mathrm{Y}=\beta 0+\beta 1 \mathrm{X} 1+\varepsilon \\
& \mathrm{Y}=\beta 0+\beta 1 \mathrm{AA}+\varepsilon
\end{aligned}
$$

Where: $\mathrm{Y}=$ Investment Strategy (percentage invested in risky assets),

$\mathrm{X} 1=$ Pension Scheme Average Age $(\mathrm{AA}), \varepsilon=$ Error term, $\beta 0=$ The Constant and $\beta 1=$ Slope of the regression equation

\section{Results}

\subsection{General Results}

\subsubsection{Occupational Retirement Benefits Schemes Average Age of Members}

The scheme with the highest average age of members was 56 years while the lowest was 30 years. The average age of scheme members for all schemes in the sample was 43.1 years. The average age of hybrid and DB schemes were 46.3 and 46.1 years respectively while that of the DC schemes was lower at 42.7 years. This is expected since the DB and hybrid schemes were established before the DC schemes and some of their members are retirees. These schemes are also closed for new members.

Table 1. Average age of scheme members per scheme design

\begin{tabular}{ll}
\hline Scheme Design & Average Age of Members \\
\hline Hybrid & 46.3 \\
DB & 46.1 \\
DC & 42.7 \\
All Schemes & 43.1 \\
\hline
\end{tabular}




\subsubsection{Occupational Retirement Benefits Schemes Scheme Design}

The defined contribution scheme design accounted for $87 \%(n=179)$, defined benefits $12 \%(n=24)$ and hybrid schemes a paltry $1 \%(\mathrm{n}=3)$ of the total schemes in the sample. This confirms the dominance of defined contribution schemes in Kenya.

\subsubsection{Investment in Risky Assets}

Overall, the schemes sampled had invested Shs 79.6 billion (US\$796 million) representing $22 \%$ of the total assets in risky assets. The $22 \%$ invested in risky assets comprised of quoted equities $20 \%$, unquoted equities and offshore investments $1 \%$ each and private equity at $0.2 \%$. This confirms that quoted equities are the most popular risky asset for pension schemes in Kenya while private equity is least popular. Hybrid schemes had invested $27 \%$ of their fund value in risky assets. DB schemes and DC schemes had invested $22 \%$ and $21 \%$ in risky assets respectively.

Table 2. Investments in risky assets per scheme design

\begin{tabular}{llll}
\hline $\begin{array}{l}\text { Scheme } \\
\text { Design }\end{array}$ & $\begin{array}{l}\text { Fund Value Shs Billion } \\
\text { (US\$ Equiv. Billion) }\end{array}$ & $\begin{array}{l}\text { Risky Assets Shs } \\
\text { Billion (US\$ Equiv. } \\
\text { Billion) }\end{array}$ & $\begin{array}{l}\text { \%age in Risky } \\
\text { Assets }\end{array}$ \\
\hline DC & $233(2.33)$ & $50.1(0.50)$ & $21 \%$ \\
DB & $109(1.09)$ & $24.3(0.24)$ & $22 \%$ \\
DB/DC & $19(0.19)$ & $5.2(0.05)$ & $27 \%$ \\
& $361(3.61)$ & $79.6(0.796)$ & $22 \%$ \\
\hline
\end{tabular}

\subsection{Results of Hypotheses Tests}

\subsubsection{Influence of Average Age on Investment Strategies}

Test of correlation between average age of scheme members and percentage of the scheme's assets invested in risky assets disclosed age had a positive but insignificant influence on investment in risk assets given $(r=.11)$ and $(p<0.112)$. Age did not significantly influence investment in any of the specific class of risky assets as indicated by the results of quoted equities $(\mathrm{r}=0.10$ and $\mathrm{p}=0.154)$, unquoted equities $(\mathrm{r}=0.057$ and $\mathrm{p}=0.418)$, investment in offshore investment $(\mathrm{r}=0.043$ and $\mathrm{p}=0.54)$ and private equity $(\mathrm{r}=-0.005$ and $\mathrm{p}=0.944)$.

The results of simple regression and analysis of variances indicate that the regression equation did not fit the data and hence age is a good predictor of scheme's investment in risky assets - F statistic $(\mathrm{df} 1,204)$ is $2.541(\mathrm{p}<0.112)$ as indicated in table 3 and 4 . The average age of the scheme members contributes to a dismal $1.2 \%$ variation in the scheme's investment in risky assets.

Table 3. Regression model of the average age on investment in risky assets

\begin{tabular}{lllll}
\hline Model & $\mathrm{R}$ & R Square & Adjusted R Square & Std. Error of the Estimate \\
\hline 1 & $.111^{\mathrm{a}}$ & .012 & .007 & .09493 \\
\hline
\end{tabular}

a. Predictors: (Constant), Average age of Scheme members

Table 4. ANOVA results on the influence of average age on investment in risky assets

\begin{tabular}{lllllll}
\hline \multirow{2}{*}{ Model } & & \multicolumn{2}{l}{ Sum } & of & & \\
1 & & Squares & Df & Mean Square & F & Sig. \\
& Regression & .023 & 1 & .023 & 2.541 & $.112^{\text {b }}$ \\
\cline { 2 - 7 } & Residual & 1.838 & 204 & .009 & & \\
& Total & 1.861 & 205 & & & \\
\hline
\end{tabular}

a. Dependent Variable: \%age Invested in Risky Assets

b. Predictors: (Constant), Average age of Scheme members 
Table 5 indicate a positive $(\mathrm{B}$ coefficient $=0.002)$ but insignificant relationship between the average age and investment in risky assets $(\mathrm{p}=0.112$.) This led to the conclusion that average age of scheme members does not influence the scheme's investment in risky assets.

Table 5: The Influence of Average Age on Investment in Risky Assets

\begin{tabular}{|c|c|c|c|c|c|c|}
\hline \multirow[b]{2}{*}{ Model } & & \multicolumn{2}{|c|}{$\begin{array}{l}\text { Unstandardized } \\
\text { Coefficients }\end{array}$} & \multicolumn{3}{|l|}{$\begin{array}{l}\text { Standardized } \\
\text { Coefficients }\end{array}$} \\
\hline & & B & Std. Error & Beta & $\mathrm{T}$ & Sig. \\
\hline \multirow{2}{*}{1} & (Constant) & .112 & .049 & & 2.274 & .024 \\
\hline & $\begin{array}{l}\text { Average age } \\
\text { Scheme members }\end{array}$ & of ${ }^{0002}$ & .001 & .111 & 1.594 & .112 \\
\hline
\end{tabular}

Dependent Variable: \%age Invested in Risky Assets.

Since the results were not in line with life cycle theory and previous studies gave contradictory results, a validation exercise of the study results was carried out with industry experts in Kenya. The investment experts explained that the average age of members does not influence scheme's decision to invest in risky assets because schemes develop one investment strategy for all members. The investment managers are unable to invest according to life cycle theory because of the need to accommodate younger and older members in one fund and report one return for all. In addition, actual investments are based on short term returns and not the strategic asset allocation which considers the average age of members weighted by their benefits balances.

Members of pension schemes in Kenya do not have a choice among conservative, moderate and aggressive funds as is the practice for pension plans in some developed markets. This role of preparing the investment strategy and asset allocation is delegated by members the board of trustees. The boards develop balanced investment strategies to take care of all the members of the scheme regardless of their age. The results of the study are in line with a number of prior studies which found no link between pension scheme members' age and investment strategy. Lucas and Zeldes (2009) study on State and Local Authorities pension schemes in the United States of America found no relationship between percentage of active pension scheme members and investment in equity. López-Villavicencio and Rigot (2013) investigated determinants of pension funds investment in private equity in US and Canada. The results indicated that occupational schemes did not take into account the age of members when investing in private equity.

Findings of various studies on the influence of average age of occupational scheme members on investment in risky assets do not agree with findings of current study. Alestalo and Puttonen (2006) study on asset allocation Finnish pension schemes found that an increase of one year in the average age of pension scheme members resulted in a decrease of 1.7 percent in equity investment. According to a research by Bikker et al., (2012) Dutch pension funds with higher average age of scheme members had a lower equity allocation than occupational schemes with lower average age. Macha and Shulia (2013) in a study of pension scheme Tanzania noted that schemes with higher ratio of active members to annuitants invested more in equities.

\section{Conclusion}

Investment strategies in line with maturity of pension scheme are better for policy makers, trustees and members since it reduces exposure to risky assets as members near retirement. The fact that maturity of schemes does not influence investment strategies should concern stakeholders in pension sector in Kenya. The Retirement Benefits Authority should introduce policy changes that will encourage schemes to offer investment choices to members based on the lifecycle theory. This should be backed by financial literacy for members by boards of trustees and employers to enable them make informed choices. The boards of trustees should include a default fund in the investment strategy for members unable or unwilling to make a choice. The study employed a cross-sectional research design while a longitudinal research design would be preferred. This was not possible due to unavailability of data over a number of years. Future studies should consider longitudinal research design and additional research on scheme maturity influence on investment strategies of pension schemes. 


\section{References}

Alestalo, N., \& Puttonen, V. (2006). Asset Allocation in Finnish Pension Funds. Journal of Pension Economics and Finance, 5, 27-44. https://doi.org/10.1017/S1474747205002295

Antolin, P., Payet, S., \& Yermo, J. (2010). Assessing the Default Investment Strategies of Defined Contribution Pension Plans. OECD Journal: Financial Market Trend. http://www.oecd.org/finance/financial-markets/46010869.pdf

Asebedo, G., \& Grable, J. (2004). Predicting Mutual Fund over Performance over a Nine-Year Period. Financial Counseling and Planning, 15(1), 1-11.

Bikker, J., Broeders, D., Hollanders, D., \& Ponds, E. (2012). Pension Funds' Asset Allocation and Participant Age: A Test of the Life - Cycle Model. Journal of Risk and Insurance, 79(3), 595-618. https://doi.org/10.1111/j.1539-6975.2011.01435.x

Boon, L., Briere, M., \& Rigot, S. (2017). Regulation and Pension Fund Risk-Taking. http://dx.doi.org/10.2139/ssrn.2475820

Brinson, G., Hood, R., \& Beebower, G. (1986). Determinants of portfolio Performance. Financial Analysts Journal, 42 (4), 39-44. https://doi.org/10.2469/faj.v42.n4.39

Brinson, G., Singer, B., \& Beebower, G. (1991). Determinants of portfolio Performance II: An Update. Financial Analysts Journal, 47(3), 40-48. https://doi.org/10.2469/faj.v47.n3.40

Deaton, A. (2005). Franco Modigliani and the Life Cycle Theory of Consumption. Paper Presented at the Convegno Internazionale Franco Modgliani, Accademia Nazionale dei Lincei, Rome. Retrieved from https://www.princeton.edu/ deaton/downloads/romelecture.pdf

Guo, Z. (2017). Health Insurance and the Demand for Medical Care: a Case Study from China. Asian Journal of Economics and Empirical Research, 4(1), 8-13. https://doi.org/10.20448/journal.501.2017.41.8.13

Hogan, P. (2007). Life-Cycle Investing Is Rolling Our Way. Financial Planning Journal, 20(5), 46-54.

Kintzel, D. (2007). Portfolio Theory, Life-Cycle Investing and Retirement Income. USA Social Security Administration Publication No. 13-11702. http://www.ssa.gov/policy/docs/policybriefs/pb2007-02.html

López-Villavicencio, A., \& Rigot, S. (2013). The Determinants of Pension Funds' Allocation to Private Equity. Retrieved from https://ssrn.com/abstract=2363356

Lucas, D., \& Zeldes, S. (2009). How Should Public Pension Plans Invest? American Economic Review, 99(2), 527-532. https://doi.org/10.1257/aer.99.2.527

Macha, S., \& Shulia, L. (2013). Unmasking the Drivers of Equity Asset Allocation: The Case of Tanzania Pension Funds. International Journal of Management Science and Business Research, 3(2), 21-31.

Massachusetts Institute of Technology (MIT). (2005). The Collected Papers of Franco Modigliani. MIT Press Cambridge, 6, 3-45

Mercer. (2016). Melbourne Mercer Global Pension Index, Australian Centre for Financial Studies, Melbourne. Retrieved from https:/www.globalpensionindex.com/wp-content/uploads/MMGPI2016-Report.pdf

NSSF. (2017). Annual Reports and Financial Statements for the Year Ended $30^{\text {th }}$ June 2016. Retrieved from www.nssf.go.ke

OECD. (2000). Pension Fund Governance, Investment Strategies, and Their Role in Corporate Governance: Note by the OECD Secretariat. Retrieved from http://www.kantakji.com/media/3376/w150.pdf

OECD. (2013). Annual Survey of Investment Regulations of Pension Funds 2013. OECD Publishing, http://www.oecd.org/daf/fin/private-pensions/invregpensionfunds2013.pdf

OECD. (2017). "Old-age dependency ratio", in Pensions at a Glance 2017: OECD and G20 Indicators. OECD Publishing, Paris. Retrieved from https://doi.org/10.1787/pension_glance-2017-22-en.

Raichura, S. (2008). Analytical Review of the Pension System in Kenya. Retrieved from http://www.oecd.org/finance/private-pensions/41564693.pdf

RBA. (2016). Retirement Benefits Industry Report for Year 2015. Media Brief December 2015. Retrieved from http://www.rba.go.ke

RBA. (2017). Retirement Benefits Industry Report for Year 2016. Retrieved from http://www.rba.go.ke 
RBA. (2018). Retirement Benefits Industry Report for Year 2017. Retrieved from http://www.rba.go.ke

Reid, C. (2014). Pension Fund Investment: Which Factors Determine the Investment Policy of Dutch Pension Funds? Retrieved from http://essay.utwente.nl/65393/1/reid_BA_MB.pdf

Stanko, D. (2002). Polish Pension Funds - Does the system work? Cost, Efficiency and Performance Measurement Issues. Retrieved from http://citeseerx.ist.psu.edu/viewdoc/download?doi=10.1.1.12.2267\&rep=rep1\&type=pdf

Towers, W. (2010). Life-cycle Strategies What Next? Retrieved from towerswatson.com

Tuelings, C., \& De Vries, C. (2006). Generational Accounting, Solidarity and Pension Losses. De Economist, (146), 63-83. https://doi.org/10.1007/s10645-006-6486-y

World Economic Forum. (2017). We'll Live to 100-How Can We Afford It? Geneva. Switzerland. Retrieved from http://www3.weforum.org/docs/WEF_White_Paper_We_Will_Live_to_100.pdf

World Health Organization. (2018). World Health Statistics 2018: Monitoring Health for SGDs, Sustainable Development Goals. WHO, Geneva. Retrieved from http://apps.who.int/iris/bitstream/handle/10665/272596/9789241565585-eng.pdf?ua=1

Yamane, T. (1967). Statistics: An Introductory Analysis. 2nd Ed., New York: Harper and Row.

\section{Copyrights}

Copyright for this article is retained by the author(s), with first publication rights granted to the journal.

This is an open-access article distributed under the terms and conditions of the Creative Commons Attribution license (http://creativecommons.org/licenses/by/4.0/). 